\title{
Rządowe Centrum Legislacji
}

\author{
Krzysztof Skotnicki \\ Uniwersytet Łódzki, Wydział Prawa i Administracji \\ Katedra Prawa Konstytucyjnego
}

1. Dyskusja na temat niskiej jakości prawa i podkreślanie, że stale się ona jeszcze pogarsza ma już bardzo długą tradycję, sięgającą bez wątpienia jeszcze lat siedemdziesiątych ubiegłego wieku. Wskazuje się w niej, że jest to wynik słabości czy wręcz wad całego procesu legislacyjnego. Proces ten jest też przedmiotem licznych analiz i formułowanych w ich następstwie postulatów. Badaniami objęta jest jednak przede wszystkich procedura stanowienia ustaw i to dopiero od chwili wystąpienia przez uprawniony podmiot z inicjatywą ustawodawczą. Jest to zrozumiałe, gdyż przesądza o tym łatwość prowadzenia ich obserwacji, która wynika z jawności prac parlamentu (istnieje prawo wstępu na posiedzenia plenarne Sejmu i Senatu, a w pewnym zakresie również na posiedzenia ich komisji oraz możliwość analizy dokumentów). Znajduje to wyraz w licznych opracowania monograficznych oraz przyczynkarskich, a także w raportach sporządzanych przez różne podmioty. Zgoła inaczej przedstawia się natomiast stan badań nad innymi etapami procesu legislacyjnego. Dotyczy to przede wszystkim przygotowania projektów ustaw przed wystąpieniem przez uprawniony podmiot $\mathrm{z}$ inicjatywą ustawodawczą, chociaż w ostatnim czasie ukazała się na ten temat bardzo intersująca monografia Macieja Berka ${ }^{1}$ i kilka drobniejszych prac przyczynkarskich, skoncentrowanych na różnych etapach tego postępowania ${ }^{2}$. W znacznie mniejszym stopniu odnosi się to natomiast do badań nad pracami nad ustawą uchwaloną przez Sejm i Senat zainicjowanymi przez Prezydenta RP, czy podjęciem decyzji o jej podpisaniu, skierowaniu do Trybunału Konstytucyjnego wniosku w sprawie jej zgodności z Konstytucją bądź przekazaniu Sejmowi do ponownego rozpatrzenia ${ }^{3}$.

1 Zob. M. Berek, Rada Ministrów jako organ inicjujący postępowanie ustawodawcze, Warszawa 2017.

2 M. Berek, Planowanie działalności legislacyjnej Rady Ministrów, „Przegląd Legislacyjny” 2011, nr 1, s. 11-27; M. Berek, Założenia do projektów ustaw - proceduralne superfluum czy obowiq̨zek demokratycznego projektodawcy, „Przegląd Legislacyjny” 2016, nr 3, s. 9-26; S. Gebethner, Propozycje doskonalenia procesu programowania (planowania) prac legislacyjnych w rządzie i Sejmie, „Przegląd Legislacyjny” 2006, nr 1; C. Kosikowski, Rada Legislacyjna przy Prezesie Rady Ministrów w procesie tworzenia prawa, „Przegląd Legislacyjny” 2006, nr 1; S. Patyra, Mechanizmy racjonalizacji procesu ustawodawczego w Polsce w zakresie rządowych projektów ustaw, Torun 2012.

3 Zob. np. R. Balicki, Weto prezydenckie jako element postępowania legislacyjnego, „Przegląd Sejmowy” 1999, nr 3, s. 42-54; J. Zaleśny, Partycypacja głowy państwa w ostatnich etapach procesu legislacyjnego, Warszawa 1999. 
Celem niniejszego opracowania jest przybliżenie państwowej jednostki organizacyjnej działającej przy Prezesie Rady Ministrów, jaką jest Rządowe Centrum Legislacji.

2. Konstytucja RP z 1997 r. określa Radę Ministrów jako jeden z organów władzy wykonawczej (art. 10 ust. 2), czyniąc z niej zarazem organ w tym segmencie główny, jako że to do niej należy prowadzenie polityki wewnętrznej i zagranicznej Rzeczypospolitej Polskiej (art. 146 ust. 1) oraz kierowanie administracją rządową (art. 146 ust. 3). W literaturze przedmiotu, co jest wyraźnie widoczne już w przypadku podręczników prawa konstytucyjnego, istnieje spora rozbieżność odnośnie do klasyfikacji funkcji, kompetencji czy zadań Rady Ministrów. Nie ulega jednak wątpliwości, że wśród nich można wyróżnić te, które są związane z tworzeniem prawa. Z jednej strony przejawia się to w konstytucyjnym prawie inicjatywy ustawodawczej, jako że Rada Ministrów, obok posłów, Senatu i Prezydenta (art. 118 ust. 1) oraz grupy co najmniej 100 tys. obywateli mających prawo wybierania do Sejmu (art. 118 ust. 2), ma prawo przedkładania Sejmowi projektu ustawy; w przypadku inicjatywy ustawodawczej w zakresie ustawy budżetowej, ustawy o prowizorium budżetowym, zmiany ustawy budżetowej, ustawy o zaciąganiu długu publicznego oraz ustawy o udzielaniu gwarancji finansowych przez państwo posiada ona przy tym wyłączność (art. 221). Rada Ministrów nie ma wprawdzie prawa stanowienia aktów o mocy ustawy (tzw. ustawodawstwo delegowane), ma jednak kompetencję do wydawania innych aktów prawa zarówno powszechnie obowiązującego, adresowanego do obywateli i innych podmiotów, tj. rozporządzeń (art. 146 ust. 4), jak i wewnętrznie obowiązującego, którego adresatem mogą być wyłącznie jednostki organizacyjne podległe Radzie Ministrów, tj. uchwał (art. 93 ust. 1). Rozporządzenia mogą być ponadto wydawane przez poszczególnych członków Rady Ministrów - Prezesa Rady Ministrów (art. 148 pkt 3) i ministrów (art. 149 ust. 2); podmioty te mogą też wydawać zarządzenia, będące aktami prawa wewnętrznego (art. 149 ust. 2).

Z logiki parlamentarno-gabinetowego systemu rządów oraz pozycji ustrojowej Rady Ministrów wynika, że powinien to być organ występujący najczęściej z inicjatywą ustawodawczą, zawsze miał on bowiem i cały czas ma najlepsze możliwości przygotowania dobrego projektu ustawy ${ }^{4}$. Rząd, premier i ministrowie wydają też inne akty prawne, stąd zrozumiałe jest, iż w złożonym procesie stanowienia prawa można wyróżnić wiele jego etapów. W przypadku inicjatywy ustawodawczej obejmują one:

4 W ostatnich latach (i nie dotyczy to wyłącznie obecnej kadencji Sejmu) nasila się, niestety, bardzo naganne zjawisko zgłaszania projektów ustaw przez grupę posłów, gdy faktycznie były one przygotowane w jednym z resortów, zaś celem takiego zachowania jest pominięcie niektórych wymogów formalnych, w szczególności konsultacji społecznych. 
1) przygotowanie projektu ustawy; 2) uzgodnienie projektu ustawy z pozostałymi członkami Rady Ministrów oraz innymi wskazanymi podmiotami; 3 ) konsultacje publiczne; 4) zasięgnięcie opinii uprawnionych podmiotów; 5) rozpatrzenie projektu przez Stały Komitet Rady Ministrów; 6) rozpatrzenie (zależnie od przedmiotu projektu - fakultatywne albo obligatoryjne) przez inne komitety Rady Ministrów oraz przez inne organy pomocnicze Rady Ministrów; 7) rozpatrzenie projektu przez komisję prawniczą; 8) rozpatrzenie projektu przez Radę Ministrów ${ }^{5}$.

Etapy te są elementami typowej procedury, w której przyjmowane są również inne dokumenty rządowe ${ }^{6}$.

3. Jednym z podmiotów uczestniczących w procesie przygotowania projektu ustawy przed wystąpieniem przez Radę Ministrów z inicjatywą ustawodawczą jest Rządowe Centrum Legislacji (dalej: RCL lub Centrum). Jego utworzenie było reakcją na inflację prawa i żywiołowy rozwój prawotwórczości poszczególnych resortów, zaś celem - stworzenie instytucji „dokonującej wstępnej selekcji impulsów legislacyjnych i koordynującej cały proces rządowych projektów ustaw”7 oraz przygotowującej projekty aktów normatywnych.

Do utworzenia RCL doszło na podstawie ustawy z dnia 24 lipca 1999 r. o zmianie ustawy o działach administracji rządowej oraz niektórych innych ustaw ${ }^{8}$, która dokonała nowelizacji ustawy z dnia 8 sierpnia 1996 r. o organizacji i trybie pracy Rady Ministrów oraz o zakresie działania ministrów ${ }^{9}$, noszącej od 2001 r. tytuł: ustawa o Radzie Ministrów ${ }^{10}$ (dalej: ustawa o RM). Był to kolejny krok w zapoczątkowanej w 1996 r. ustrojowej reformie rządu ${ }^{11}$. W nowelizowanej ustawie dodano wówczas blok artykułów poświęconych tworzonemu Rządowemu Centrum Legislacji. Funkcjonowanie RCL reguluje również uchwała nr 190 Rady Ministrów z dnia 29 października 2013 r. - Regulamin pracy Rady Ministrów ${ }^{12}$. Szczególne

5 Zob. M. Berek, Rada Ministrów..., s. 78.

6 Zob. ibidem.

7 Zob. M. Wróblewska, Rola Rządowego Centrum Legislacji w procesie tworzenia prawa, „Folia Iuridica Universitatis Wratislaviensis" 2016, vol. 5 (1), s. 54.

8 Dz.U. nr 70, poz. 778.

9 Dz.U. nr 106, poz. 492 ze zm.

10 Zmiana tytułu ustawy nastąpiła na podstawie ustawy z dnia 21 grudnia 2001 r. o zmianie ustawy o organizacji i trybie pracy Rady Ministrów oraz o zakresie działania ministrów, ustawy o działach administracji rządowej oraz o zmianie niektórych ustaw, Dz.U. nr 154, poz. 1800.

$11 \mathrm{Na}$ reformę tę składało się 10 ustaw przyjętych między czerwcem a sierpniem $1996 \mathrm{r}$., wśród których oprócz przywołanej ustawy o organizacji i trybie pracy Rady Ministrów oraz o zakresie działania ministrów należy odnotować ustawy z 21 czerwca 1996 r. o: urzędzie Ministra Finansów i izbach skarbowych (Dz.U. nr 106, poz. 489), urzędzie Ministra Gospodarki (Dz.U. nr 106, poz. 490), urzędzie Ministra Spraw Wewnętrznych i Administracji (Dz.U. nr 106, poz. 491) oraz ustawy z 8 sierpnia 1996 r. o: urzędzie Ministra Skarbu Państwa (Dz.U. nr 106, poz. 493), Komitecie Integracji Europejskiej (Dz.U. nr 106, poz. 494), Rządowym Centrum Studiów Strategicznych (Dz.U. nr 106, poz. 495).

12 M.P., poz. 979. 
znaczenie ma wreszcie kilkakrotnie nowelizowane zarządzenie nr 79 Prezesa Rady Ministrów z dnia 28 czerwca 2002 r. w sprawie nadania statutu Rządowego Centrum Legislacji ${ }^{13}$.

W ustawie o RM ustanowiono, że RCL działa przy Prezesie Rady Ministrów oraz określono, że jest to „państwowa jednostka organizacyjna podległa Prezesowi Rady Ministrów" (art. 14a), mająca na celu koordynowanie działalności legislacyjnej Rady Ministrów, Prezesa Rady Ministrów i innych organów administracji rządowej (art. 14b).

Początkowo Rządowe Centrum Legislacji funkcjonowało w strukturze Kancelarii Prezesa Rady Ministrów, obecnie jest jednak z niej wyodrębnione.

4. Zgodnie z art. 14e ustawy o RM, Rządowym Centrum Legislacji kieruje prezes RCL przy pomocy wiceprezesów oraz dyrektorów komórek organizacyjnych. Kolejne przepisy bardzo szczegółowo określają wymogi stawiane kandydatom na te stanowiska oraz procedurę przeprowadzania na nie konkursu, z podkreśleniem, że ma on mieć charakter otwarty i konkurencyjny. Konkurs przeprowadza zespół powołany przez szefa Kancelarii Prezesa Rady Ministrów z upoważnienia Prezesa Rady Ministrów. Konkurs wyłania nie więcej niż trzech kandydatów na stanowisko, którzy są następnie przedstawiani szefowi Kancelarii Prezesa RM. Prezesa i wiceprezesów RCL powołuje i odwołuje Prezes Rady Ministrów, przy czym wiceprezesi RCL powoływani są na wniosek prezesa RCL. Przepisy nie określają przy tym liczby wiceprezesów RCL. W momencie powstawania tego opracowania jest dwóch wiceprezesów RCL.

Struktura organizacyjna RCL na przestrzeni lat ulegała zmianie i jej obecny kształt został nadany nowelizacją z 17 maja 2016 r. ${ }^{14}$ Początkowo były to tylko trzy departamenty legislacyjne oraz Redakcja Dziennika Ustaw Rzeczypospolitej Polskiej i Dziennika Urzędowego Rzeczypospolitej Polskiej „Monitor Polski” ${ }^{15}$. Obecnie, zgodnie z $\$ 4$ ust. 1 statutu, w skład RCL wchodzą następujące komórki organizacyjne: 1) Departament Prawa Administracyjnego; 2) Departament Prawa Gospodarczego; 3) Departament Prawa Pracy, Rodziny i Infrastruktury; 4) Departament Prawny i Postępowań przed Trybunałem Konstytucyjnym; 5) Departament Dzienników Urzędowych i Tekstów Jednolitych; 6) Biuro Administracyjne; 7) Biuro Finansowe. Ponadto prezes RCL może tworzyć samodzielne wydziały oraz wielo- i jednoosobowe stanowiska pracy ( $\$ 4$ ust. 2 statutu). Szczegółowy zakres zadań poszczególnych komórek określa regulamin organizacyjny nadany przez Prezesa Centrum ( $\$ 5$ statutu).

13 Tekst jedn. M.P. z 2017 r., poz. 282.

14 M.P., poz. 450.

15 Zob. M. Wróblewska, Rola Rządowego Centrum Legislacji..., s. 55. 


\section{Zgodnie z art. 14c ustawy, zadania Centrum to:}

1) opracowywanie rządowych projektów ustaw na zasadach i w trybie określonych w Regulaminie pracy Rady Ministrów, chyba że na podstawie odrębnych przepisów opracowywanie określonych rodzajów projektów ustaw należy do właściwości innych podmiotów;

2) opracowywanie stanowisk prawno-legislacyjnych do rządowych projektów aktów prawnych innych niż określone w pkt 1 oraz do projektów założeń projektów ustaw;

3) opracowywanie pod względem legislacyjnym rządowych projektów aktów prawnych innych niż określone w pkt 1, skierowanych do rozpatrzenia przez Radę Ministrów, w tym poprzez ich ocenę pod względem prawnym i redakcyjnym przez Komisję Prawniczą prowadzoną przez Centrum;

3a) zapewnienie udziału Rady Ministrów i Prezesa Rady Ministrów w postępowaniu przed Trybunałem Konstytucyjnym;

4) analizowanie orzecznictwa Trybunału Konstytucyjnego, Sądu Najwyższego i Naczelnego Sądu Administracyjnego, a także Trybunału Sprawiedliwości Wspólnot Europejskich i Sądu Pierwszej Instancji w szczególności w zakresie wpływu na polski system prawa;

5) koordynowanie pod względem prawnym i formalnym przebiegu uzgodnień rządowych projektów aktów prawnych;

6) wydawanie, z upoważnienia Prezesa Rady Ministrów, na zasadach i w trybie określonych w odrębnych przepisach, Dziennika Ustaw Rzeczypospolitej Polskiej oraz Dziennika Urzędowego Rzeczypospolitej Polskiej „Monitor Polski”;

7) współdziałanie z ministrem właściwym do spraw członkostwa Rzeczypospolitej Polskiej w Unii Europejskiej w sprawie dostosowania prawa polskiego do prawa Unii Europejskiej i jego wykonywania;

8) współdziałanie z Radą Legislacyjną w zakresie opiniowania rządowych projektów aktów normatywnych pod względem ich zgodności z Konstytucją Rzeczypospolitej Polskiej oraz spójności z polskim systemem prawa;

9) monitorowanie wydawania przez organy administracji rządowej przepisów wykonawczych do ustaw;

10) wykonywanie innych zadań określonych w odrębnych przepisach lub wskazanych przez Prezesa Rady Ministrów".

Oceniając powyższe zadania, trudno nie zauważyć, że nie są to uprawnienia władcze i pozwalające w jakikolwiek sposób na współdecydowanie czy wyraźny wpływ na rządowy proces legislacyjny ${ }^{16}$.

Pewien wyjątek stanowi opracowywanie projektów ustaw na zasadach i w trybie określonych w Regulaminie pracy Rady Ministrów, co jest zadaniem nowym, dodanym (w 2011 r.) w następstwie krytyki wcześniejszego żywiołowego i łatwego tworzenia projektów ustaw na etapie inicjowania prac legislacyjnych, akcentowanego braku jawności i przejrzystości tworzenia prawa w rządzie oraz wyrażanego postulatu potrzeby stworzenia instytucji zajmującej się całościowo tworzeniem prawa na etapie rządowym ${ }^{17}$. Podkreślano, że „Rządowe Centrum Legislacji i Rada

16 Zob. S. Wronkowska, Tworzenie prawa w Polsce - ocena i poprawne kierunki zmian. Raport Rady Legislacyjnej przy prezesie Rady Ministrów, „Przegląd Legislacyjny” 2006, nr 1, s. 13.

17 Zob. M. Wróblewska, Rola Rządowego Centrum Legislacji..., s. 57-58. 
Legislacyjna zajmują się jedynie technicznymi aspektami tworzenia prawa"18. Małgorzata Wróblewska stwierdza wręcz, że

Wprawdzie powołaniu RCL przyświecała idea ograniczenia negatywnych skutków funkcjonującego resortowego modelu tworzenia prawa, jednak z perspektywy czasu, mając na względzie określone pierwotnie zadania, można stwierdzić, że RCL nie miało większego wpływu na resortowy model tworzenia prawa. RCL było jednostką pozostającą poza głównym nurtem procesu tworzenia prawa. Jego uprawnienia wobec ministrów były znikome ${ }^{19}$.

Konstrukcja rozwiązania przyjętego $\mathrm{w}$ art. 14c pkt 1 ustawy o RM jest prosta - rząd przyjmuje założenia projektu ustawy, natomiast sam projekt ustawy opracowuje RCL we współpracy z organem wnioskującym, którym z reguły jest minister i który przedkłada szczegółowe propozycje niezbędnych regulacji. Maciej Berek ocenia to jako schemat: decyzja merytoryczna co do istoty, praca legislacyjna, decyzja finalna co do projektu aktu ${ }^{20}$. Procedura ta ma także spowodować właściwe wykorzystanie zasobów personalnych administracji rządowej, gdyż urzędników-legislatorów jest niezwykle mało i stale toczy się dyskusja, czy powinni być oni rozproszeni $\mathrm{w}$ wyodrębnionych jednostkach $\mathrm{w}$ ramach struktury każdego ministerstwa, czy też skomasowani w ramach jednej jednostki, jaką jest Rządowe Centrum Legislacji ${ }^{21}$. Przyjęcie tego rozwiązania powinno zapobiec również pewnej występującej od lat nagannej praktyce powierzania opracowywania projektów ustaw podmiotom zewnętrznym, co - jak słusznie zauważa Maciej Berek - „zwiększa [...] ryzyko związane z nieformalnym oddziaływaniem na treść projektu, a co najmniej ogranicza możliwość skutecznego wdrożenia mechanizmów takim wpływom przeciwdziałających"22. Podzielając ten pogląd, wyrażam jednak wątpliwości odnośnie do umiejętności pisania tekstów prawnych przez te podmioty, gdyż są to przede wszystkim kancelarie adwokackie bądź radcowskie. Sztuka napisania dobrego projektu ustawy to umiejętność wyjątkowa. Stąd zawód legislatora to szczególna biegłość, której nie posiada w Polsce zbyt wiele osób. Dlatego legislatorzy powinni znajdować się w grupie najlepiej zarabiających urzędników państwowych, gdyż to od nich w dużej (o ile nie w przeważającej) mierze zależy jakość stanowionego prawa. Niestety, zbyt często osoby te przenoszą się do pracy w miejsca, gdzie są znacznie lepiej wynagradzani. Powinni oni funkcjonować w każdym ministerstwie, gdyż dzięki temu łatwiej byłoby im ująć w język prawny rozwiązania właściwe dla „swojego" resortu, którego specyfikę znają i rozumieją. Dlatego jestem ostrożny z powierzaniem tego zadania wyłącznie legislatorom z Rządowego Centrum Legislacji, którzy - moim zdaniem - powinni włączać się

18 Zob. W. Staśkiewicz, Stanowienie prawa, [w:] L. Kolarska-Bobińska (red.), Co warto, co należy zmienić. Poprawa jakości demokracji w Polsce, Warszawa 2008, s. 45 i n.

19 Zob. M. Wróblewska, Rola Rzq̨dowego Centrum Legislacji..., s. 58.

20 Zob. M. Berek, Rada Ministrów..., s. 241.

21 Ibidem, s. 82.

22 Ibidem, s. 80-81. 
w proces legislacyjny na późniejszym etapie prac nad projektem ustawy. Dobrze jest dlatego, że w większości ministerstw funkcjonują legislatorzy w ramach departamentów prawno-legislacyjnych (chociaż są i takie, w których, niestety, brak urzędników o takich kwalifikacjach).

Przepisy Regulaminu pracy Rady Ministrów dopuszczają też jednak inne rozwiązanie, zgodnie bowiem $\mathrm{z} \ 24$ ust. 1 organ wnioskujący sam podejmuje prace nad projektem dokumentów rządowych, jeżeli opracowanie danego dokumentu wynika w szczególności z: 1) obowiązujących przepisów; 2) konieczności wdrożenia lub wykonania prawa Unii Europejskiej; 3) dokonanych analiz i ocen stanu prawnego lub sytuacji społeczno-gospodarczej, w tym uwzględniających konsultacje zagadnień z danej dziedziny życia społeczno-gospodarczego. Jak podkreśla Anna Młynarska-Sobaczewska, pozwala to na przygotowywanie projektów rządowych w resortach, a nie w Radzie Ministrów czy w Rządowym Centrum Legislacyjnym, co też w praktyce ma najczęściej miejsce ${ }^{23}$.

Zgodnie z $\$ 71-73$ Regulaminu pracy Rady Ministrów organ wnioskujący kieruje projekt do Rządowego Centrum Legislacji, w którym jego rozpatrzeniem zajmuje się komisja prawnicza powoływana przez prezesa RCL; $w$ tym celu prezes wskazuje ministerstwa i urzędy, których przedstawiciele mają obowiązek wziąć udział w jej posiedzeniu. Komisja ma otrzymać komplet materiałów, w tym uzasadnienie projektu oraz ocenę przewidywanych skutków społeczno-gospodarczych (tzw. OSR), opinię o zgodności z prawem Unii Europejskiej oraz projekty aktów wykonawczych. Komisja, obradująca zawsze pod przewodnictwem przedstawiciela RCL, ocenia projekt pod względem prawnym, legislacyjnym i redakcyjnym, w szczególności zgodność przepisów projektu z obowiązującym systemem prawa i zasadami techniki prawodawczej, jak również uwzględnienie opinii Rady Legislacyjnej oraz poprawność językową ( $\$ 75$ ust. 1 Regulaminu pracy Rady Ministrów).

Cel tego rozwiązania jest oczywisty i jest nim zapewnienie właściwej jakości redakcyjno-legislacyjnej projektu, który ma być przedłożony Radzie Ministrów. Na podstawie $₫ 78$ ust. 1 Regulaminu pracy Rady Ministrów istnieje jednak możliwość zwolnienia $\mathrm{w}$ uzasadnionych przypadkach przez prezesa RCL projektu aktu normatywnego, gdy jego jakość nie budzi zastrzeżeń, z potrzeby rozpatrzenia przez komisję prawniczą. W piśmiennictwie jest to oceniane pozytywnie jako rozwiązanie racjonalizujące procedurę ${ }^{24}$. W praktyce ma też miejsce wiele odstępstw od założonego trybu postępowania z projektami dokumentów rządowych, w tym w szczególności z projektami ustaw. Niestety, niezwykle często wyznaczane są zbyt krótkie terminy na rozpatrzenie projektu w RCL oraz nadużywana jest klauzula

23 Zob. A. Młynarska-Sobaczewska, Proces legislacyjny a jakość stanowienia prawa, [w:] S. Patyra, M. Sadowski, K. Urbaniak (red.), Konstytucja w państwie demokratycznym, Poznań 2017, s. 143.

24 Zob. M. Berek, Rada Ministrów..., s. 111. 
pilności (w znaczeniu praktycznym, nie konstytucyjnym), co sprawia, że efektywne wywiązanie się z zadania oceny redakcyjno-legislacyjnej projektu jest mało realne, zaś część uwag przekazywanych jest po jego upływie - a trzeba pamiętać, że zgodnie $\mathrm{z}$ art. 40 ust. 4 regulaminu istnieje domniemanie, iż brak opinii w terminie jest równoznaczny z akceptacją projektu ${ }^{25}$. Coraz częściej dostrzegana jest również sytuacja naruszania założonego trybu prac nad projektem ustawy i trudno jest ustalić, w jaki sposób doszło do jego opracowania ${ }^{26}$.

6. Omawiając Rządowe Centrum Legislacji, nie można zapomnieć o innych bardzo ważnych zadaniach, które ono wykonuje.

Przede wszystkim należy w tym przypadku wskazać na analizowanie orzecznictwa sądów polskich (Trybunału Konstytucyjnego, Sądu Najwyższego i Naczelnego Sądu Administracyjnego) oraz Trybunału Sprawiedliwości Wspólnot Europejskich i Sądu Pierwszej Instancji (z uwzględnieniem wpływu, jaki mają na polski system prawa). RCL podjął takie działania jeszcze przed formalnym upoważnieniem; aktualnie zadanie to wynika $\mathrm{z}$ art. 14c ustawy o RM i obowiązuje od 1 kwietnia 2009 r. Szczególne znaczenie przywiązuje się do analizy orzecznictwa Trybunału Konstytucyjnego ${ }^{27}$. Jest to widoczne w upoważnieniu, jakie Prezes Rady Ministrów udzielił - na podstawie $\$ 8$ pkt 1 Regulaminu pracy Rady Ministrów - prezesowi RCL do opracowywania, uzgadniania i wnoszenia pod obrady Rady Ministrów projektów aktów prawnych mających na celu wykonywanie tych orzeczeń. W tym celu RCL „podjęło działania mające na celu bieżące monitorowanie rozstrzygnięć Trybunału Konstytucyjnego oraz usunięcie uregulowań prawnych zakwestionowanych w tych orzeczeniach. Działania te są prowadzone systematycznie, a ich celem jest dążenie do uporządkowania systemu prawa, uwzględniającego orzecz-

25 Zob. ibidem, s. 86-87.

26 Z sytuacją taką bardzo wyraźnie mieliśmy do czynienia w przypadku ustawy z 27 czerwca 2018 r. o zmianie ustawy o Instytucie Pamięci Narodowej - Komisji Ścigania Zbrodni przeciwko Narodowi Polskiemu oraz ustawy o odpowiedzialności podmiotów zbiorowych za czyny zabronione pod groźbą kary (Dz.U. z 2018 r. poz. 1277), której projekt został przyjęty przez Radę Ministrów (podobnie jak wiele innych projektów ustaw) w trybie obiegowym i wpłynął do Sejmu jeszcze przed przedstawieniem opinii Ministerstwa Spraw Zagranicznych, zaś w bazie Rządowego Centrum Legislacyjnego został zamieszczony dopiero w kilka godzin po nadaniu mu w Sejmie numeru druku (zob. A. Brzuszkiewicz, Rządowy projekt nowelizacji ustawy o IPN powstał w ,żadnym trybie” zaledwie dzień wcześniej, „Dziennik Łódzki” 2018, nr z 28 czerwca, s. 7). W przypadku tej ustawy prace w Sejmie i Senacie, podobnie jak jej podpisanie przez prezydenta, odbyły się jednego dnia; prezydent tego dnia przebywał przy tym na Łotwie, a podpis złożył za pomocą laptopa wyposażonego w szyfrowany komponent podpisu elektronicznego (http://300polityka.pl, dostęp: 27.06.2018).

27 Zob. P. Gryska, Rola Rządowego Centrum Legislacji w wykonywaniu wyroków Trybunału Konstytucyjnego, [w:] Księga XXV-lecia Trybunału Konstytucyjnego. Ewolucja funkcji i zadań Trybunału Konstytucyjnego - założenia a ich praktyczna realizacja, Warszawa 2010, s. 205-210. 
nictwo Trybunału Konstytucyjnego"28. Do 2010 r. opracowano 18 projektów takich ustaw ${ }^{29}$, a w 2015 r. było 20 projektów ustaw wykonujących wyroki Trybunału Konstytucyjnego opracowanych przez RCL i przyjętych przez Radę Ministrów ${ }^{30}$. Działania RCL przynoszą też oczekiwane zmiany w prawie ${ }^{31}$.

Stosunkowo od niedawna na RCL nałożono obowiązek zapewnienia obsługi prawnej Rady Ministrów poprzez zapewnienie udziału Rady Ministrów i Prezesa Rady Ministrów przed Trybunałem Konstytucyjnym. W tym celu RCL przygotowuje stanowiska Rady Ministrów i Prezesa RM w sprawie będącej przedmiotem rozprawy przed Trybunałem Konstytucyjnym.

Sporadycznie do RCL przekazywane są adresowane do administracji rządowej petycje odnoszące się do redakcji obowiązujących przepisów prawa bądź zasad techniki legislacyjnej, a także braku publikacji wyroków Trybunału Konstytucyjnego ${ }^{32}$.

Obok redagowania Dziennika Ustaw i Monitora Polskiego od 1 stycznia 2016 r. do RCL, na podstawie art. 16 ust. 2 znowelizowanej ustawy z 20 lipca 2000 r. o ogłaszaniu aktów normatywnych i niektórych innych aktów prawnych ${ }^{33}$, należy również obowiązek współdziałania z Marszałkiem Sejmu przy opracowywaniu tekstów jednolitych ustaw.

Za bardzo ważne zadanie Rządowego Centrum Legislacji uznać należy prowadzenie aplikacji legislacyjnej. Zadanie to nałożone jest na Centrum przez $₫ 1$ rozporządzenia Prezesa Rady Ministrów z 28 kwietnia 2015 r. w sprawie aplikacji legislacyjnej ${ }^{34}$. Aplikacja skierowana jest do urzędników administracji rządowej - ale nie tylko - zainteresowanych procesem stanowienia prawa, którzy uczestniczą bądź w przyszłości przewidują udział w jego tworzeniu; specyfika naboru na tę aplikację polega na tym, że nie ma on charakteru otwartego ${ }^{35}$.

28 Zob. https://rcl.gov.pl (dostęp: 20.06.2018).

29 Zob. P. Gryska, Rola Rzq̨dowego Centrum Legislacji..., s. 207. W pracy tej omówione są też te projekty.

30 Podaję za: M. Wróblewska, Rola Rządowego Centrum Legislacji..., s. 61.

31 Przykładem może być rozporządzenie Ministra Rodziny, Pracy i Polityki Społecznej z dnia 24 sierpnia 2017 r. zmieniające rozporządzenie w sprawie szczegółowego przeznaczenia, warunków i trybu udzielania przez Agencję Rynku Rolnego wypłat w ramach realizacji Programu Operacyjnego Pomoc Żywnościowa 2014-2020, Dz.U. z 2017 r., poz. 1622.

32 Na stronie internetowej Rządowego Centrum Legislacji znajduje się pięć takich petycji, w tym m.in. z 9 marca 2018 r. odnosząca się do nieopublikowania wyroków Trybunału Konstytucyjnego. Zob. https://rcl.gov.pl (dostęp: 20.06.2018).

33 Tekst jedn. Dz.U. z 2017 r., poz. 1523.

34 Dz.U. z 2015 r., poz. 587.

35 Na aplikację odbywaną w edycji 2018/2019 zakwalifikowano 52 osoby. Są to głównie urzędnicy z ministerstw oraz po kilka osób z Kancelarii Prezesa Rady Ministrów i Rządowego Centrum Legislacji, ale też z Agencji Bezpieczeństwa Wewnętrznego, komend głównych: Policji, Żandarmerii Wojskowej i Straży Granicznej, Narodowego Funduszu Zdrowia, Urzędu Lotnic- 
Wśród nowych zadań RCL należy wskazać stworzenie przez Centrum, w związku z ustawą z 6 września 2001 r. o dostępie do informacji publicznej ${ }^{36}$, platformy informatycznej „Rządowy Proces Legislacyjny”, na której zamieszczane są informacje o podjęciu przez organy administracji rządowej prac nad projektami aktów normatywnych.

7. Utworzenie przed blisko 20 laty Rządowego Centrum Legislacji miało na celu nie tylko zahamowanie wyraźnie widocznej, stale pogarszającej się i od dawna krytykowanej niskiej jakości stanowionego w Polsce prawa, lecz także odwrócenie tej tendencji. Można mieć jednak wątpliwości, czy tak się stało.

Jak już sygnalizowałem, nie jestem przekonany o słuszności przyjętej konstrukcji, zgodnie z którą projekty aktów prawnych, a przede wszystkim ustaw, na podstawie przyjętych wcześniej przez Radę Ministrów założeń do projektu ustawy powinni opracowywać wyłącznie legislatorzy z Centrum. Legislatorzy są niezbędni również $\mathrm{w}$ poszczególnych ministerstwach, gdyż pracując tam, lepiej rozumieją specyfikę resortu, w którym są zatrudnieni, a tym samym łatwiejsze jest dla nich ujęcie $\mathrm{w}$ przepisie prawnym proponowanego rozwiązania. Łatwe jest też do przewidzenia, że w praktyce poszczególni legislatorzy z RCL będą w sposób mniej bądź bardziej formalny odpowiadać za współpracę z konkretnym ministerstwem, a tym samym wykształci się swoista ich specjalizacja. Jestem zdania, iż legislatorzy RCL powinni współpracować z legislatorami w poszczególnych resortach - nie powinno mieć miejsca dalsze procedowanie projektu aktu prawnego bez jego akceptacji w Centrum pod względem prawnym.

Znacznie poważniejszą przyczyną pogłębiającej się niskiej jakości stanowionego w Polsce prawa jest jednak to, że zarówno podczas prac nad nim w rządzie, jak i później w trakcie prac nad ustawą w Sejmie i w Senacie dopuszczalne jest skracanie procedury. Są to jednak sytuacje, za które Rządowe Centrum Legislacji nie odpowiada, jak również sytuacje, w których ustawy uchwalane są w ekspresowym tempie, bez wykorzystania procedury przewidzianej w art. 123 ust. 1 Konstytucji. Przyjęcie dobrego prawa wymaga namysłu i rozwagi, na co potrzebny jest czas. Mam świadomość, że będą pojawiać się sytuacje, w których natychmiastowe uchwalenie ustawy czy wydanie innego aktu prawnego będzie niezbędne. Możliwość takiego działania powinna mieć jednak miejsce tylko wyjątkowo i najlepiej, gdyby była obwarowana ścisłymi przesłankami czy wręcz wymogami formalnymi, których spełnienie na to zezwoli (np. większość trzech piątych głosów przy obecności co najmniej połowy ustawowego składu Sejmu). Długi przebieg prac nad powstającym prawem niewątpliwie zmniejsza ryzyko powstawania pomyłek i zapobiega obserwowanemu nie tylko w obecnych kadencjach Sejmu i Senatu no-

twa Cywilnego czy urzędów wojewódzkich, zaskakuje natomiast przyjęcie osoby z Klubu Parlamentarnego PiS. Zob. https://rcl.gov.pl (dostęp: 30.06.2018).

Tekst jedn. Dz.U. z 2016 r., poz. 1764 ze zm. 
welizowaniu ustaw wkrótce po, a często nawet jeszcze przed ich wejściem w życie. Należy też pamiętać, że po wyborach politycy zwycięskiego ugrupowania z reguły nie darzą nadmiernym zaufaniem urzędników pracujących w ministerstwach czy innych rządowych agendach i wolą zwracać się o pomoc do innych osób, które jednak niekoniecznie dysponują wystarczającą wiedzą fachową; nieufność ta odnosi się także do legislatorów z Rządowego Centrum Legislacji.

Natomiast powierzanie RCL innych zadań odnoszących się do pozyskiwania całościowej wiedzy o polskim, europejskim i międzynarodowym prawie, jak i zadań z obszaru informatyki niewątpliwie zasługuje na pełną aprobatę.

\section{Santrauka}

\section{Vyriausybès teisèkūros centras}

Vyriausybès teisèkūros centras yra pavaldi Ministrų Tarybos pirmininkui valstybinė ìstaiga, kurios tikslas koordinuoti Ministrų Tarybos, Ministrų Tarybos pirmininko ir kitų vyriausybės administracijos padalinių teisèkūrinę veiklą. Šiam centrui vadovauja VTC pirmininkas, padedant pirmininko pavaduotojams bei centro padalinių direktoriams.

VTC sukūrimas $1999 \mathrm{~m}$. buvo pagrịstas idejja, kad dabartinis ịstatymų projektų rengimas atskirose ministerijose turètų būti pakeistas siekiant, kad ministerijose būtų sukurti tik teisès aktų projektų pagrindai, kurie po vèlesnių susitarimų su Ministrų Tarybos nariais bus perduoti VTC, kuris parengs visą įstatymo projektą, kurị prieš igyvendinant įstatymų leidybos iniciatyvos teisę išnagrinès Ministrų Taryba. Autorius nèra įsitikinęs šio sprendimo pagrịstumu, nes gali kilti klausimas, ar ministerijų teisèkūrininkai negali tinkamai teisine kalba išdėstyti šių sutartų pagrindų ị teisès aktų projektą.

Kita vertus, reikia įvertinti VTC vykdomą Konstitucinio Tribunolo, Aukščiausiojo Teismo ir Aukščiausiojo Administracinio Teismo, taip pat Europos Sajungos Teisingumo Teismo ir Pirmosios instancijos teismo jurisprudencijos analizę, ypatingą dėmesį skiriant šios doktrinos įtakai Lenkijos teisès sistemai bei teikiant pasiūlymus atitinkamai ją keisti.

Kitos VTC užduotys, be kita ko, yra tokių leidinių kaip „Istatymų dienraštis“ (lenk. „Dziennik Ustaw“) ir „Lenkijos monitorius“ (lenk. „Monitor Polski“) leidimas, bendradarbiavimas su Seimo Pirmininku rengiant vienodus teisės aktų projektų tekstus, teisinių paslaugų teikimas Ministrų Tarybai, tokiu būdu užtikrinant Ministrų Tarybos ir Ministro Pirmininko kvalifikuotą dalyvavimą Konstitucinio Tribunolo teisminiame procese, teisèkūros paraiškų rengimas vyriausybès administracijos tarnautojams, IT platformos „Vyriausybès įstatymų leidybos procesas“ (lenk. „Rządowy Proces Legislacyjny“), kurioje pateikiama informacija apie vyriausybės administracijos padalinių pradètą darbą rengiant norminių teisès aktų projektus, kūrimas ir valdymas. 


\section{Literatura}

Balicki R., Weto prezydenckie jako element postępowania legislacyjnego, „Przegląd Sejmowy" 1999, nr 3.

Berek M., Planowanie działalności legislacyjnej Rady Ministrów, „Przegląd Legislacyjny” 2011, nr 1 .

Berek M., Rada Ministrów jako organ inicjujacy postępowanie ustawodawcze, Warszawa 2017.

Berek M., Założenia do projektów ustaw - proceduralne superfluum czy obowiązek demokratycznego projektodawcy, „Przegląd Legislacyjny” 2016, nr 3.

Brzuszkiewicz A., Rzadowy projekt nowelizacji ustawy o IPN powstat $w$ „żadnym trybie” zaledwie dzień wcześniej, „Dziennik Łódzki” 2018, nr z 28 czerwca.

Gebethner S., Propozycje doskonalenia procesu programowania (planowania) prac legislacyjnych w rządzie i Sejmie, „Przegląd Legislacyjny” 2006, nr 1.

Gryska P., Rola Rządowego Centrum Legislacji w wykonywaniu wyroków Trybunału Konstytucyjnego, [w:] Ksiega XXV-lecia Trybunału Konstytucyjnego. Ewolucja funkcji i zadań Trybunału Konstytucyjnego - założenia a ich praktyczna realizacja, Warszawa 2010.

Kosikowski C., Rada Legislacyjna przy Prezesie Rady Ministrów w procesie tworzenia prawa, „Przegląd Legislacyjny” 2006, nr 1.

Młynarska-Sobaczewska A., Proces legislacyjny a jakość stanowienia prawa, [w:] S. Patyra, M. Sadowski, K. Urbaniak (red.), Konstytucja w państwie demokratycznym, Poznań 2017.

Patyra S., Mechanizmy racjonalizacji procesu ustawodawczego $w$ Polsce $w$ zakresie rządowych projektów ustaw, Torun 2012.

Staśkiewicz W., Stanowienie prawa, [w:] L. Kolarska-Bobińska (red.), Co warto, co należy zmienić. Poprawa jakości demokracji w Polsce, Warszawa 2008.

Wronkowska S., Tworzenie prawa w Polsce - ocena i poprawne kierunki zmian. Raport Rady Legislacyjnej przy prezesie Rady Ministrów, „Przegląd Legislacyjny” 2006, nr 1.

Wróblewska M., Rola Rządowego Centrum Legislacji w procesie tworzenia prawa, „Folia Iuridica Universitatis Wratislaviensis" 2016, vol. 5 (1).

Zaleśny J., Partycypacja głowy państwa w ostatnich etapach procesu legislacyjnego, Warszawa 1999.

\section{Akty prawne}

Ustawa z dnia 21 czerwca 1996 r. o urzędzie Ministra Finansów oraz urzędach skarbowych, Dz.U. nr 106, poz. 489.

Ustawa z dnia 21 czerwca 1996 r. o urzędzie Ministra Gospodarki, Dz.U. nr 106, poz. 490. Ustawa z dnia 21 czerwca 1996 r. o urzędzie Ministra Spraw Wewnętrznych i Administracji, Dz.U. nr 106, poz. 491.

Ustawa z dnia 8 sierpnia 1996 r. o organizacji i trybie pracy Rady Ministrów oraz o zakresie działania ministrów, Dz.U. nr 106, poz. 492. 
Ustawa z dnia 8 sierpnia 1996 r. o urzędzie Ministra Skarbu Państwa, Dz.U. nr 106, poz. 493.

Ustawa z dnia 8 sierpnia 1996 r. o Komitecie Integracji Europejskiej, Dz.U. nr 106, poz. 494.

Ustawa z dnia 8 sierpnia 1996 r. o Rządowym Centrum Studiów Strategicznych, Dz.U. nr 106, poz. 495.

Ustawa z dnia 24 lipca 1999 r. o zmianie ustawy o działach administracji rządowej oraz niektórych innych ustaw, Dz.U. nr 70, poz. 778.

Ustawa z 20 lipca 2000 r. o ogłaszaniu aktów normatywnych i niektórych innych aktów prawnych, tekst jedn. Dz.U. z 2017 r., poz. 1523.

Ustawa z 6 września 2001 r. o dostępie do informacji publicznej, tekst jedn. Dz.U. z 2016 r., poz. 1764 ze zm.

Ustawa z dnia 21 grudnia 2001 r. o zmianie ustawy o organizacji i trybie pracy Rady Ministrów oraz o zakresie działania ministrów, ustawy o działach administracji rządowej oraz o zmianie niektórych ustaw, Dz.U. nr 154, poz. 1800.

Rozporządzenie Prezesa Rady Ministrów z dnia 28 kwietnia 2015 r. w sprawie aplikacji legislacyjnej, Dz.U. z 2015 r., poz. 587.

Rozporządzenie Ministra Rodziny, Pracy i Polityki Społecznej z dnia 24 sierpnia 2017 r. zmieniające rozporządzenie w sprawie szczegółowego przeznaczenia, warunków i trybu udzielania przez Agencję Rynku Rolnego wypłat w ramach realizacji Programu Operacyjnego Pomoc Żywnościowa 2014-2020, Dz.U. z 2017 r., poz. 1622.

Uchwała nr 190 Rady Ministrów z dnia 29 października 2013 r. - Regulamin pracy Rady Ministrów, M.P. poz. 979.

Zarządzenie nr 79 Prezesa Rady Ministrów z dnia 28 czerwca 2002 r. w sprawie nadania statutu Rządowego Centrum Legislacji, tekst jedn. M.P. z 2017 r., poz. 282.

\section{Strony internetowe}

http://300polityka.pl (dostęp: 27.06.2018).

https://rcl.gov.pl (dostęp: 20.06.2018). 